\title{
Rozdział 12
}

\section{Współczesne przemiany koryta i równiny zalewowej 0dry}

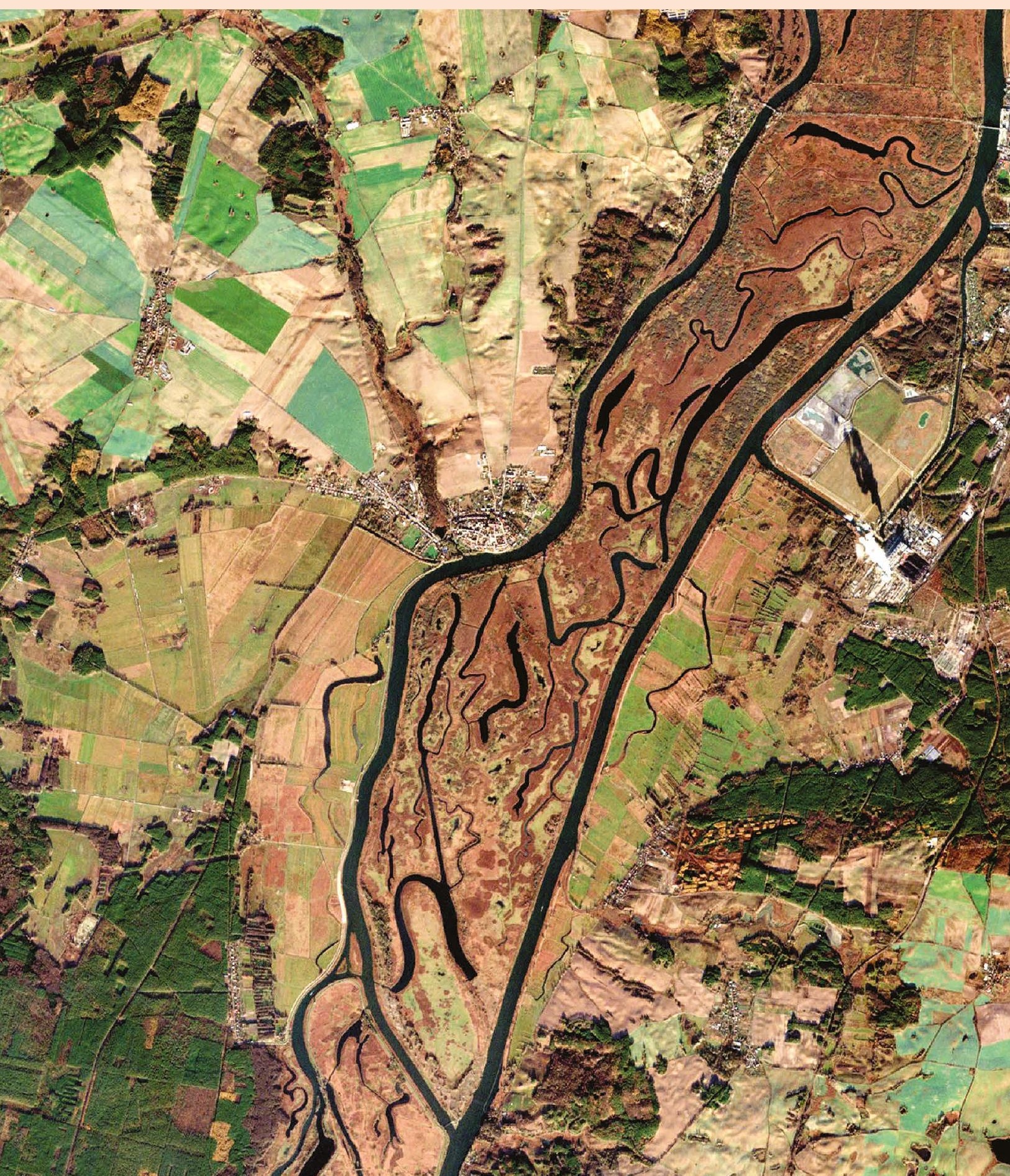


Dolna Odra (ESA/Copernicus) 
W: Wspótczesne przemiany rzeźby Polski, A. Kostrzewski, K. Krzemień, P. Migoń, L. Starkel, M. Winowski, Z. Zwoliński (red.), Bogucki Wydawnictwo Naukowe, Poznań, 2021 https://doi.org/10.12657/9788379863822-12

\section{Rozdział 12 \\ Współczesne przemiany koryta i równiny zalewowej 0dry}

(C) (1)

\section{Dariusz Ciszewski, Agnieszka Czajka}

\subsection{Charakterystyka doliny rzeki 0 dry}

\subsubsection{Fizjografia doliny 0 dry}

Dorzecze Odry ma powierzchnię $118861 \mathrm{~km}^{2}$, co stanowi 32,9\% powierzchni kraju. W granicach Polski znajduje się $106821 \mathrm{~km}^{2}$ jej dorzecza, w granicach Czech $-6453 \mathrm{~km}^{2}$, a na terenie Niemiec $5587 \mathrm{~km}^{2}$. Dorzecze Odry ma charakter nizinny, gdyż tereny powyżej $300 \mathrm{~m}$ n.p.m. zajmują jedynie $21,4 \%$ jej obszaru, a poniżej 100 m n.p.m. - 24\% (Dubicki 1993, Nalberczyński 1993). Odra wypływa w położonych w Czechach Górach Oderskich na wysokości $634 \mathrm{~m}$ n.p.m. Jej długość wynosi 854,3 km, z czego w granicach Polski znajduje się 741,9 km.

W dorzeczu Odry wyróżnia się sześć obszarów o odmiennych cechach orograficznych i hydrograficznych: górne, środkowe i dolne dorzecze Odry oraz dorzecza Warty, Nysy Łużyckiej i Zalewu Szczecińskiego (Plan... 2010). Za obszar zlewni górnej Odry przyjmuje się tereny zamknięte granicą zlewni Nysy Kłodzkiej oraz zlewni Małej Panwi. Dorzecze środkowej Odry sięga niemal ujścia Warty, podczas gdy dorzecze dolnej Odry sięga jej ujścia do Zalewu Szczecińskiego. Duży udział dopływów rzek górskich w odpływie z obszaru górnej i środkowej Odry ma wpływ na znaczną zmienność przepływów rzeki. Cechą charakterystyczną tej części dorzecza Odry jest wyraźna dominacja licznych, lewobrzeżnych, obfitujących w wodę dopływów górskich nad nielicznymi, prowadzącymi mniej wody rzekami nizinnymi. Z kolei dorzecze Warty, o powierzchni 54529 km², w większości stanowią tereny nizinne, ze znacznym udziałem terenów zalesionych oddziałujących wyrównawczo na przepływ Odry. Podczas gdy dorzecze górnej i środkowej Odry ma powierzchnię $53536 \mathrm{~km}^{2}$, powierzchnia dorzecza dolnej Odry (od ujścia Warty) wynosi jedynie $10796 \mathrm{~km}^{2}$ (Głowicki i in. 1993, Dubicki 2002). Na tym odcinku wahania stanów wody zależą od zasilania z obszaru górnej i środkowej 
Odry i Warty, ale także, od wodowskazu w Gozdowicach - od cofki Zalewu Szczecińskiego.

Obecny przebieg doliny Odry kształtował się wskutek procesów morfogenetycznych zachodzących głównie w okresie plejstocenu. Odpływ wód fluwioglacjalnych na przedpolu lądolodu zachodził w kierunku zachodnim systemem pradolin, podczas gdy pomiędzy tymi pradolinami występowały przełomowe odcinki doliny. $\mathrm{Z}$ powodu naprzemiennego występowania odcinków południkowych i równoleżnikowych dolina Odry na terenie Polski wielokrotnie gwałtownie zmienia swój kierunek. Kotlina Raciborska, w której południkowo biegnąca dolina Odry ma szerokość dochodzącą do $6 \mathrm{~km}$, kończy się 1,5-kilometrowej szerokości zwężeniem wykształconym w utworach triasowych. Dalej dolina Odry wykorzystuje fragment Pradoliny Wrocławsko-Magdeburskiej o szerokości dochodzącej do $10 \mathrm{~km}$. Poniżej Malczyc na obszarze Obniżenia Ścinawskiego, o szerokości dochodzącej do $20 \mathrm{~km}$, dolina ponownie ma przebieg południkowy. Dalej Odra wykorzystuje odcinek Pradoliny Barucko-Głogowskiej o przebiegu NW-SE, a następnie Kotlinę Kargowską. Z kolei równoleżnikowo biegnąca dolina w Pradolinie Warszawsko-Berlińskiej kończy się w malowniczym południkowym odcinku Lubuskiego Przełomu Odry. Dolina Odry rozszerza się do kilkunastu kilometrów na terenie Pradoliny Toruńsko-Eberswaldzkiej, którą wykorzystuje także rzeka Warta, i Doliny Dolnej Odry ograniczonej kilkudziesięciometrowej wysokości skarpami na prawym brzegu rzeki.

Miąższość osadów czwartorzędowych występujących w dolinie Odry sięga przeważnie kilkudziesięciu metrów (Galon 1972), natomiast osadów holoceńskich - kilkunastu metrów (Czerwiński 1998). Osady te są wyraźnie sterasowane w wyniku stopniowego wcinania się wód płynących doliną Odry u schyłku vistulianu i w holocenie. Przeważnie obserwuje się system czterech teras o wysokości od $1 \mathrm{~m}$ do kilkunastu metrów nad poziom wody (Badura, Przybylski 2000). W rzeźbie doliny w dolnym biegu Odry zaznaczają się systemy terasowe $z$ tego okresu o wysokości $18-22 \mathrm{~m}, 12-15 \mathrm{~m}, 6,5-8 \mathrm{~m}$ i 1-2 m (Borówka 2003). Najmłodsza i najniższa holoceńska równina zalewowa, zbudowana głównie z piasków i żwirów, jest nadbudowywana utworami facji powodziowych o przeciętnej miąższości 2-3 $\mathrm{m}$, a w wypełnieniach starorzeczy 3,5 m. Utwory powodziowe są zbudowane z osadów bardziej drobnoziarnistych, głównie piasków drobnoziarnistych, piasków pylastych i pyłów (Badura, Przybylski 2000).

Spadek rzeki Odry w górnym biegu, powyżej granicznego wodowskazu w Chałupkach, wynosi 0,7\%o, a na odcinku od granicy do ujścia Kłodnicy 0,39\%o. Spadek zmniejsza się z biegiem rzeki, od 0,38\%o w Pradolinie Wrocławsko-Magdeburskiej i 0,32\%o w Pradolinie Barucko-Głogowskiej, do 0,28\%o w Pradolinie Warszawsko-Berlińskiej. Poniżej ujścia Nysy Łużyckiej spadek ten zmniejsza się poniżej 0,25\%o. Jeszcze mniejszy jest poniżej ujścia Warty i wynosi 0,17\% w Kotlinie Freienwalde i 0,04\%o w 75-kilometrowym przyujściowym odcinku. 


\subsubsection{Hydrologia rzeki Odry}

Średni roczny przepływ górnej Odry wynosi około $60 \mathrm{~m}^{3} \cdot \mathrm{s}^{-1}$ (Krzyżanowice), jednak w czasie niżówek jesiennych jest on nawet 2-3-krotnie niższy. Wezbrania w górnym, ale także w środkowym biegu formują się przeważnie w miesiącach wiosennych oraz w lipcu i sierpniu (Jankowski, Křriž 1996). Przepływy wody w pewnym stopniu kształtowane są też pod wpływem zrzutów wód kopalnianych oraz przerzutów wód ze zlewni Wisły (Absalon i in. 1997, Matysik 2018). W górnym biegu Odry wahania przepływów wody są największe. Stosunek ich wartości ekstremalnych WWQ/NNQ wynosi ponad 200 (Jankowski, Świerkosz 1995), a uwzględniając powódź z 1997 r. - ponad 300. Również relacja między wysokimi i niskimi przepływami średnimi (ŚWQ/ŚNQ) jest największa, niemal 30-krotna.

Wahania stanów wód szybko zmniejszają się w środkowym biegu rzeki. Dopływy rzek nizinnych oraz niewielki udział obszarów górskich w powierzchni zlewni środkowej Odry powodują, że wartość WWQ/NNQ na długim odcinku rzeki waha się w granicach 30-60 (Jankowski, Świerkosz 1995). W Oławie przepływy Odry w strefie przepływów niskich i średnich wzrastają trzykrotnie w stosunku do górnego odcinka Odry, natomiast przepływy wysokie - zaledwie 15$20 \%$ i kształtują się $\mathrm{W}$ przedziale $31,2-3550 \mathrm{~m}^{3} \cdot \mathrm{s}^{-1}$. W Ścinawie średni przepływ Odry wynosi około $180 \mathrm{~m}^{3} \cdot \mathrm{s}^{-1}$, jednak w czasie niżówek może on zmniejszyć się nawet do $23 \mathrm{~m}^{3} \cdot \mathrm{s}^{-1}$. Przykładowe wartości przepływów średnich dopływów Odry w ich odcinkach ujściowych, w stosunku do przepływów Odry, wynoszą: dla Nysy Kłodzkiej (Skorogoszcz) 28\%, Bobru (Żagań) 14\%, Nysy Łużyckiej (Gubin) 10\% (Ciszewski, Dubicki 2008). Wartość WWQ/NNQ w środkowym biegu spada od 60 do 30 (Jankowski, Świerkosz 1995), a uwzględniając powódź z 1997 r. - od 110 do 40. Dużo mniejsze są także różnice pomiędzy średnimi przepływami (ŚWQ/ ŚNQ) wynoszące od $11 \mathrm{w}$ Oławie do $7 \mathrm{w}$ Połęcku. W Ścinawie średni przepływ Odry wynosi około $190 \mathrm{~m}^{3} \cdot \mathrm{s}^{-1}$. Jednak w czasie niżówek może on zmniejszyć się nawet do $35 \mathrm{~m}^{3} \cdot \mathrm{s}^{-1}$. Średni roczny przepływ Odry w dolnym odcinku wynosi około $500 \mathrm{~m}^{3} \cdot \mathrm{s}^{-1} \mathrm{i}$ jest tylko 2,5 razy większy niż przepływ minimalny. Wpływ dużej ilości wód Warty, o stosunkowo niewielkich wahaniach przepływu, powoduje również zmniejszenie wahań przepływów ekstremalnych na dolnej Odrze do 12 (Jankowski, Świerkosz 1995). Spływ wód roztopowych z dorzecza Warty często powoduje długotrwałe utrzymywanie się przepływów pozakorytowych na dolnej Odrze w miesiącach wiosennych. Wielokrotnie wysoki stan wód jest podtrzymywany wskutek piętrzenia wód Zalewu Szczecińskiego przez sztormy.

Średni odpływ jednostkowy na przeważającej części dorzecza Odry kształtuje się $\mathrm{w}$ przedziale $2,5-7,5 \mathrm{dm} \cdot \mathrm{s}^{-1} \cdot \mathrm{km}^{-2}$ (w latach 1961-1990). Jedynie obszary górskie Sudetów i Beskidów Śląsko-Morawskich charakteryzują się wyższymi odpływami $7,64-18,5 \mathrm{dm} \cdot \mathrm{s}^{-1} \cdot \mathrm{km}^{-2}$. Zlewnia Odry rozdzielona jest izoreją odpowiadającą wielkości średniego wysokiego odpływu (Swq) $50 \mathrm{dm} \cdot \mathrm{s}^{-1} \cdot \mathrm{km}^{-2}$ na mniej więcej dwie połowy. Wartości odpływu jednostkowego (Swq) wyższe od $50 \mathrm{dm} \cdot \mathrm{s}^{-1} \cdot \mathrm{km}^{-2}$ występują na obszarach Przedgórza Sudeckiego, Sudetów i Beskidu Śląsko-Morawskiego. Natomiast znacznie niższe $z$ tych wartości są charakterystyczne dla 
terenów nizinnych i zlewni rzek o charakterze przejściowym, w większości położonych na wschód i północny wschód od linii Odry (Ciszewski, Dubicki 2008).

\subsection{Historia regulacji 0 dry}

Współczesne procesy fluwialne zachodzące w korycie Odry są uwarunkowane regulacją wykonaną na niemal całej długości rzeki. Obecnie jedynie od granicy państwa do ujścia Olzy koryto Odry zachowało naturalny, meandrowy charakter. Jakkolwiek modyfikacja koryta rzeki była lokalnie wykonywana jeszcze w średniowieczu w pobliżu miast nadodrzańskich, dopiero regulacja zapoczątkowana w połowie XVIII w., po zajęciu Śląska przez Prusy w czasie wojny austriacko-pruskiej i prowadzona w systematyczny sposób w XIX i w początkach XX w., spowodowała istotne zmiany $\mathrm{w}$ przebiegu koryta. Początkowo głównym celem było skrócenie Odry poprzez przekopy meandrów o największej krzywiźnie dla ułatwienia żeglugi, przyspieszenia spływu wód powodziowych oraz ochrony przed erozją budowanych w wielu miejscach wałów przeciwpowodziowych. Ponieważ prace wykonywano ręcznie, a do przewozu ziemi używano koni, starano się je przeprowadzić stosunkowo najmniejszym nakładem wysiłku, a więc i kosztów. W tym celu wykopywano rów o szerokości około $4 \mathrm{~m}$ i następnie rozszerzano na przemian $z$ lewej i z prawej strony. Skutkiem tego woda musiała płynąć zygzakowatym nurtem, intensywnie erodując rozkopane brzegi (Born 1948). Do 1782 r. wykonano 48 przekopów, które spowodowały skrócenie Odry o $60 \mathrm{~km}$. Niewątpliwie gwałtowne zwiększenie ilości transportowanego materiału musiało przyczynić się do dziczenia rzeki i trudnej do kontrolowania erozji przylegających do rzeki gruntów, ale także szybkiego zasypywania dawnych zakoli, zwłaszcza w ich części proksymalnej. Problemy, jakie spowodował taki sposób regulacji, m.in. powstawanie mielizn, wpadające do rzeki drzewa, obecność pali starych mostów (w wielu miejscach uniemożliwiających jakąkolwiek żeglugę), wymusiły modyfikację postępowania. Nowy sposób, który zaczęto stosować około 1800 r., polegał na budowie ostróg. Do ich konstrukcji używano wiązek wikliny układanych na przemian $z$ warstwami ziemi i piasku, a zalądowane pomiędzy nimi baseny były utrwalane wikliną. Ostrogi te jednak nie wszędzie ustabilizowały koryto rzeki. W wielu miejscach ich nierównomierne i niewłaściwe rozmieszczenie stało się przyczyną zwiększenia krętości nurtu i erozji niektórych odcinków brzegów. Można przypuszczać, że na początku XIX w. Odra w dolnym biegu transportowała ilości rumowiska dennego, znacznie większe od ilości obserwowanych w drugiej połowie XX w., wynoszących około 300-350 $000 \mathrm{t} \cdot \mathrm{a}^{-1}$ (Łajczak 2005).

Problemy wynikające $z$ dotychczasowej regulacji oraz wzrastające od końca XVIII w. wydobycie węgla i budowa Kanału Kłodnickiego w latach 1792-1812 stały się impulsem do wykorzystania Odry do celów żeglugowych. Zaplanowano systematyczną regulację Odry, której założenia przyjęto w 1819 r. w tzw. Protokole Bogumińskim. Przewidywał on zawężenie koryta rzeki, którego skutkiem miało być usunięcie mielizn i wykształcenie głębokości umożliwiającej żeglugę 
od Raciborza podczas trwania średnich stanów wody (Koziarski 1997). Ustalono regularnie zmieniającą się z biegiem rzeki szerokość koryta o przebiegu krzywoliniowym, możliwie zbliżonym do naturalnego (Muszyński 1948). Przyjętą głębokość i szerokość koryta Odry osiągano w czasie regulacji trwających w XIX i XX w. (tab. 12.1). Od 1842 r. rozpoczęto budowę ostróg kamiennych, często obrukowanych, ale nierzadko tylko pokrytych faszyną i kamieniami. Doprądowy kierunek ostróg ułatwiał akumulację osadów w basenach międzyostrogowych. Większość zaplanowanych prac od Kędzierzyna do Świecka wykonano do 1885 r. Regulacja środkowego odcinka Odry między Wrocławiem i ujściem Warty spowodowała akumulację erodowanych osadów w niżej położonych odcinkach. Szczególnie okresowe zwiększenie ilości transportowanego rumowiska spowodowało nasilenie się powodzi w dolnym biegu w latach 1829-1845. Wymusiło to budowę ostróg zawężających koryto także w tym odcinku w latach 1850-1885 (Born 1948) oraz kolejne modyfikacje biegu rzeki i budowę polderów według tzw. planu Heuera (Unikalna dolina... 2015). Już w trakcie prac okazało się, że potrzeby transportowe są coraz większe i drogę wodną należy dostosować do barek o nośności 400 ton. Również częste niskie stany wody utrudniały uzyskanie głębokości większych niż $60 \mathrm{~cm}$. Spowodowało to konieczność ponownego zawężenia koryta rzeki i umocnienia jej brzegów. Powołana w 1874 r. Komisja Regulacji Rzeki Odry określiła głębokość $1 \mathrm{~m}$ jako konieczną do uzyskania w nurcie przy średnich niskich stanach wody. W tym celu należało skanalizować odcinek Odry powyżej Wrocławia, a odcinek pomiędzy Wrocławiem i ujściem Warty zawęzić o około $25 \mathrm{~m}$ (tab. 12.1). Kanalizację Odry wykonano na 187-kilometrowym odcinku pomiędzy Koźlem i Wrocławiem. Między Koźlem i ujściem Nysy Kłodzkiej w latach 1891-1896 wybudowano 12 stopni wodnych, a także śluzy i port rzeczny w Koźlu. Równocześnie w latach 1892-1897 rozbudowano drogę wodną - porty, śluzy i kanały na terenie Wrocławia. W latach 1907-1915 kontynuowano kanalizację

Tabela 12.1. Zmiany szerokości koryta Odry w wyniku regulacji od XVIII do połowy XX w. (Ciszewski 2006)

\begin{tabular}{lcccc}
\hline & \multicolumn{4}{c}{ Szerokość koryta [m] } \\
\cline { 2 - 5 } Miejscowość & $\begin{array}{c}\text { Koryto } \\
\text { naturalne } \\
\text { (XVIII w.) }\end{array}$ & $\begin{array}{c}\text { Koryto } \\
\text { skrócone } \\
(1 \text { połowa } \\
\text { XIX w. })\end{array}$ & $\begin{array}{c}\text { Koryto uregulowane } \\
(1 \text { poł. XX w.) }\end{array}$ \\
\hline Krzyżanowice & $70-120$ & $70-120$ & wg ustaleń & wg ustaleń \\
zoźle & $70-150$ & $70-150$ & 719 r. & z 1874 r. \\
Oława & $150-250$ & $120-250$ & $90-93$ & \\
Uraz & $150-170$ & $120-150$ & $105-113$ & 76 \\
Ścinawa & $200-250$ & $150-200$ & 120 & 102 \\
Nowa Sól & $200-300$ & $130-250$ & 139 & 124 \\
Słubice & $250-350$ & $200-250$ & 150 & \\
Gozdowice & $250-450$ & & 150 & \\
\hline
\end{tabular}


Odry pomiędzy Nysą Kłodzką i Wrocławiem, kończąc ją na stopniu Różanka. Ogółem zbudowano 9 stopni wodnych, na których jeszcze później, aż do 1942 r., modernizowano śluzy i inne elementy mechaniczne. W 1923 r. zbudowano stopień wodny w Rędzinie poniżej Wrocławia, w latach 1948-1958 - w Brzegu Dolnym. W 1939 r. oddano do użytku Kanał Gliwicki. Ogółem na tym skanalizowanym odcinku istnieją 24 stopnie, na których spadek rzeki wynosi $50 \mathrm{~m}$. Mimo istnienia przed wojną projektów mających polepszyć żeglowność Odry poniżej Wrocławia, nie zdecydowano się na przeprowadzenie jej kanalizacji ze względu na niskie położenie i dużą szerokość dna doliny, które mogłoby zostać wskutek tego podtopione. Szczególnie jednak wzrosłoby zagrożenie jej zalania w czasie powodzi. Ponowna regulacja Odry poniżej Wrocławia poprzez zawężenie jej regularnym systemem ostróg została przeprowadzona w latach 1924-1939 i objęła odcinek od Rędzina $(261 \mathrm{~km})$ do Lubusza $(594 \mathrm{~km})$. Niedokończone w czasie wojny prace na odcinku $54 \mathrm{~km}$, między Lubuszem i ujściem Warty, zostały wykonane po II wojnie światowej (Koziarski 1997).

Ostrogi (tamy poprzeczne), które miały kluczowy wpływ na wielkość i zróżnicowanie akumulacji osadów, konstruowano w tym odcinku według wspólnych zasad. Budowano je naprzeciwko siebie tak, aby ich przedłużenia przecinały się w osi trasy regulacyjnej. Kąt, jaki tworzą tamy z osią trasy regulacyjnej, wynosi około $75^{\circ}$. Odstępy pomiędzy ostrogami wzrastają wraz z szerokością koryta. Przy brzegu wklęsłym odstępy mogą być mniejsze, a na wypukłym większe. W zakrętach o dużej krzywiźnie budowano także ostrogi (tamy) równoległe, a przestrzenie między brzegiem i tymi ostrogami wypełniono materiałem pochodzącym z brzegów. Stopa ostrogi była konstruowana z faszyny, na którą narzucano kamienie, a następnie piasek i żwir. Powierzchnia ostróg była obrukowana kamieniami i zaokrąglona dla zmniejszenia uszkodzeń spowodowanych spływem wody lub lodu. Szerokość korony ostrogi wynosiła $2 \mathrm{~m}$. Również brzegi umacniano narzutem kamiennym i faszyną, szczególnie wzmacniając połączenie ostrogi z brzegiem, będące miejscem narażonym na erozję w czasie powodzi (Muszyński 1948).

Od 1945 r. stale, choć z różnym natężeniem, prowadzi się prace zmierzające do utrzymania Odry jako rzeki żeglownej, głównie obejmujące modernizację śluz i ich urządzeń napędowych. Do 1996 r. wykonano także na odcinku skanalizowanym 17 jazów. Poniżej wybudowanego po II wojnie światowej progu w Brzegu Dolnym wystąpiła szybka, przekraczająca 2 m, erozja denna. Wymusiło

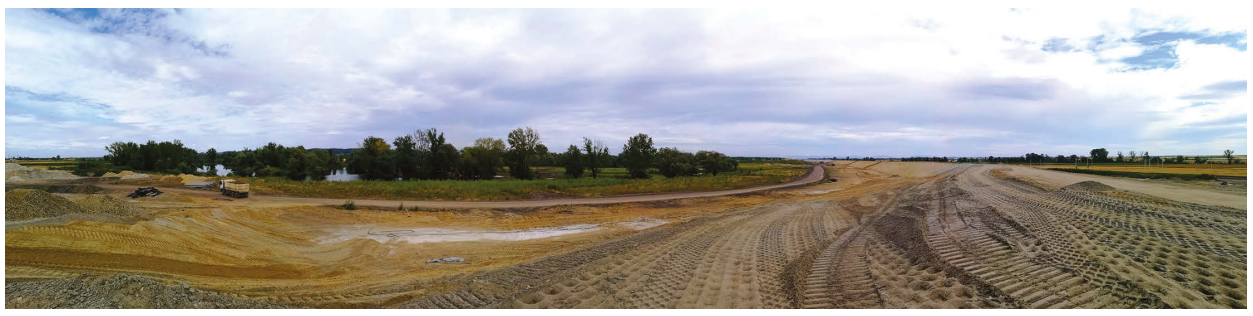

Ryc. 12.1. Budowa zbiornika Racibórz w miejscowości Sudół. Stan na lipiec 2019 r. (fot. A. Czajka) 
to rozpoczęcie budowy stopnia wodnego w Malczycach, ukończonej w 2019 r., na którym dziś kończy się Odra skanalizowana. Jest on jednym z kilku progów proponowanych do wykonania dla dalszej poprawy żeglowności środkowej Odry (Kubec 2004). W ramach programu Odra 2006 wykonano też liczne poldery w: Raciborzu, Koźlu, Dąbrówce, Chróścicach, Kotowicach, Widawie, Rakowie, Domaszkowie, Rzymkówce, trwa również budowa zbiornika wodnego w Raciborzu (ryc. 12.1). Inwestycjom tym towarzyszą zmiany linii brzegowej, z budową nowych ostróg i umocnień włącznie (Zaleski Winter, 2000).

\subsection{Procesy i osady fluwialne Odry uregulowanej}

W górnym biegu Odry skrócenie koryta, zapoczątkowane w 1786 r., wyniosło $36 \%$, powodując zwiększenie spadku poniżej ujścia Olzy o $37 \%$, do $0,4 \mathrm{~m} \cdot \mathrm{km}^{-1}$ (Czajka 2005). Zwiększenie spadku koryta oraz jego 2-krotne zwężenie zainicjowało z kolei gwałtowną erozję i pogłębianie. Skalę zmian geometrii koryta pokazuje porównanie koryt w meandrach odciętych w wyniku regulacji pod koniec XVIII w., z korytem współczesnym w odcinku pomiędzy 62 a $65 \mathrm{~km}$ biegu rzeki w rejonie Grzegorzowic (ryc. 12.2). Parametry przedregulacyjnego koryta Odry znacznie odbiegają od parametrów koryta współczesnego (tab. 12.2). Naturalne koryto Odry miało w badanym odcinku nawet ponad 190 m szerokości, a dzisiejsze w najszerszym miejscu ma zaledwie $50 \mathrm{~m}$. Oznacza to, że uregulowana Odra jest węższa od naturalnej nawet o $150 \mathrm{~m}$. Z kolei dno współczesnego koryta Odry leży miejscami ponad 3 m poniżej poziomu koryta naturalnego.

Erozji sprzyjają największe w całym biegu Odry wahania przepływów wody. Erozja koryta, zachodząca w ostatnich 30 latach, najintensywniej w wyżej położonym odcinku pomiędzy Miedonią i granicą państwa w Chałupkach, jest istotnym źródłem transportowanych osadów. Ich ładunek, wraz z osadami dostarczanymi przez dopływy: Olzę i Psinę, wyniósł w latach 1978-1990 około 280000 t•a $\mathrm{a}^{-1}$.

Tabela 12.2. Szerokość i położenie dna współczesnego i przedregulacyjnego koryta Odry w rejonie Grzegorzowic (S - Sławików, S II - Sławików II, G - Grzegorzowice, T - Turze, T II - Turze II, C, C2 - Ciechowice)

\begin{tabular}{lcccccc}
\hline & $\begin{array}{c}\text { Szerokość } \\
\text { koryta } \\
\text { przed } \\
\text { regulacją } \\
{[\mathrm{m}]}\end{array}$ & $\begin{array}{c}\text { Szerokość } \\
\text { koryta } \\
\text { dzisiaj } \\
{[\mathrm{m}]}\end{array}$ & $\begin{array}{c}\text { Różnica } \\
\text { szerokości } \\
{[\mathrm{m}]}\end{array}$ & $\begin{array}{c}\text { Poziom } \\
\text { dna przed } \\
\text { regulacją } \\
{[\mathrm{m} \text { n.p.m. }]}\end{array}$ & $\begin{array}{c}\text { Współcze- } \\
\text { sny } \\
\text { poziom dna } \\
{[\mathrm{m} \text { n.p.m. }}\end{array}$ & $\begin{array}{c}\text { Różnica } \\
\text { poziomów } \\
{[\mathrm{m}]}\end{array}$ \\
\hline S & 123 & 44 & -79 & 177,3 & 174,1 & $-3,3$ \\
S II & 165 & 43 & -122 & 176,7 & 173,5 & $-3,1$ \\
\hline T & 142 & 32 & -110 & 177,2 & 174,0 & $-3,2$ \\
T II & 70 & 47 & -23 & 176,6 & 173,1 & $-3,5$ \\
C & 100 & 50 & -50 & 175,9 & 173,2 & $-2,7$ \\
G & 193 & 42 & -151 & 173,3 & 173,2 & $-0,1$ \\
\hline
\end{tabular}



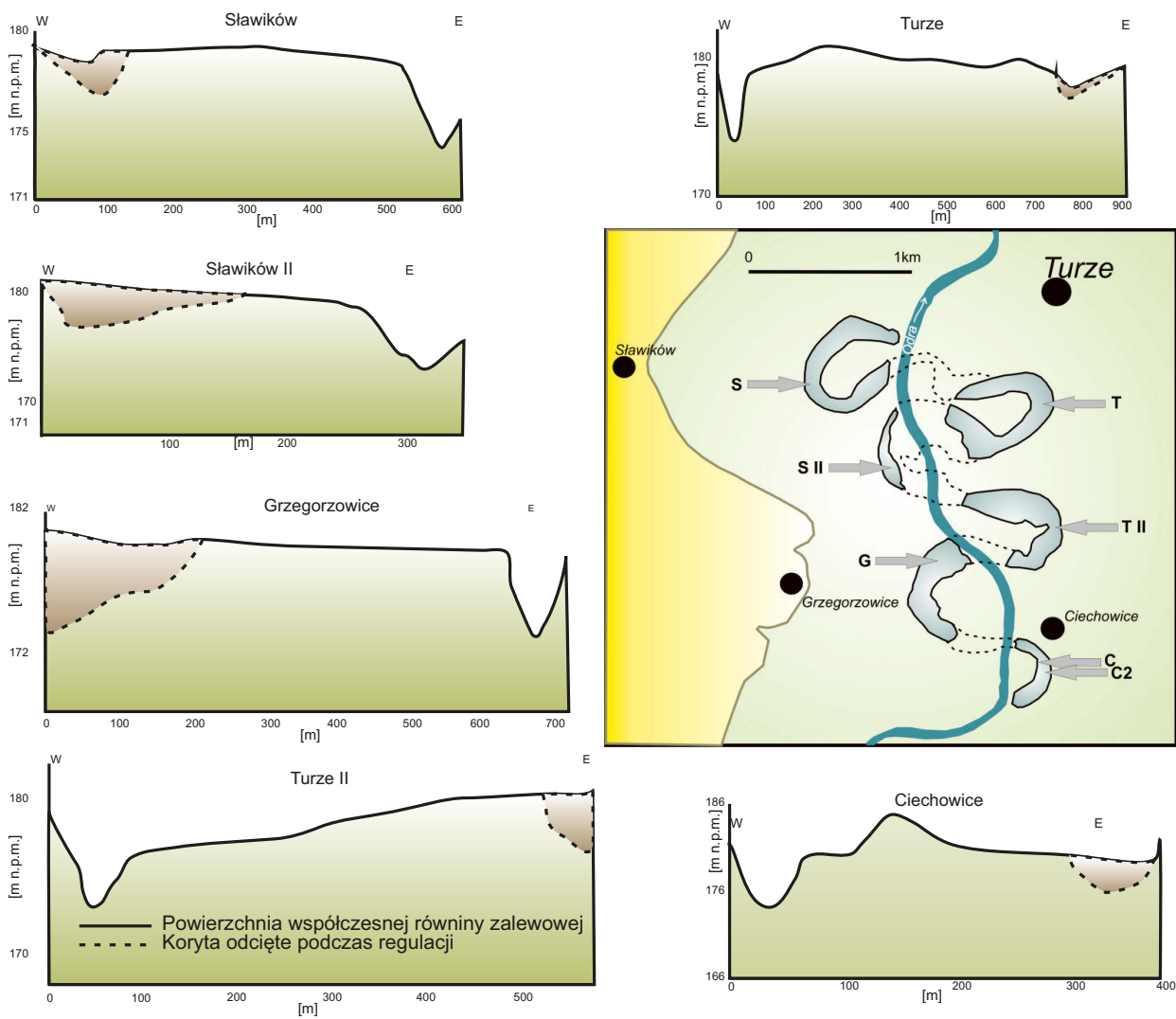

Ryc. 12.2. Różnice geometrii między współczesnym i XVIII-wiecznym korytem Odry w rejonie Grzegorzowic (S - Sławików, S II - Sławików II, G - Grzegorzowice, T - Turze, T II - Turze II, C, C2 - Ciechowice)

Nawet ponad $80 \%$ osadów transportowanych podczas wezbrań akumulowało się na równinie zalewowej powyżej Miedoni. Wielkość ładunku wahała się jednak w zależności od pory wystąpienia wezbrania najczęściej pomiędzy 50-60\%, wynosząc około $5500 \mathrm{t} \cdot \mathrm{a}^{-1}$ (Czajka 2004). W korycie uregulowanym formy denne występują stosunkowo rzadko w porównaniu z odcinkiem meandrowym, gdyż są rozmywane łatwo z powodu dużych prędkości wody występujących w czasie wezbrań, a także wskutek intensywnej eksploatacji osadów prowadzonej w miejscach powstawania łach. Eksploatacja powoduje generalnie ujemny bilans transportowanych osadów w tym odcinku (Czajka, Nadudvari 2016).

Najszybsze narastanie osadów pozakorytowych ma miejsce przy brzegach poregulacyjnego koryta chronionego nieregularnymi ostrogami. Wiek wykonania przekopów skracających zakola oraz znajdowane w osadach artefakty pozwalają ocenić tempo depozycji przy założeniu jego stałości w uzyskanych okresach. Przeciętne roczne tempo przyrostu tych osadów jest szybkie i waha się od 1 do 
$10 \mathrm{~cm}$, a ich miąższość wynosi od 2 do $4 \mathrm{~m}$ (Czajka 2005). Cechą charakterystyczną tych osadów jest ich wyraźne warstwowanie (ryc. 12.3.).

Naprzemiennie występują jasne warstwy piasków drobno- i średnioziarnistych, przedzielone brunatnoczarnymi warstwami o większej zawartości frakcji drobniejszych oraz dużej zawartości materii organicznej. W warstwach tych powszechnie spotykane są okruchy węgla, tworzące bardziej lub mniej widoczną laminację (ryc. 12.4).

Ponadto powszechne jest zanieczyszczenie tych osadów metalami ciężkimi, pochodzącymi $z$ kopalń i innych zakładów przemysłowych Ostrawsko-Karwińskiego Okręgu Przemysłowego, o zawartościach przekraczających wielokrotnie wielkości tła geochemicznego (Ciszewski 2006). W spągu tych osadów występują łachy koryta funkcjonującego $\mathrm{w}$ momencie regulacji, $\mathrm{w}$ wielu miejscach pokryte otoczakami dawnego bruku korytowego. Dziś ich powierzchnia jest zawieszona nawet $2 \mathrm{~m}$ nad przeciętny

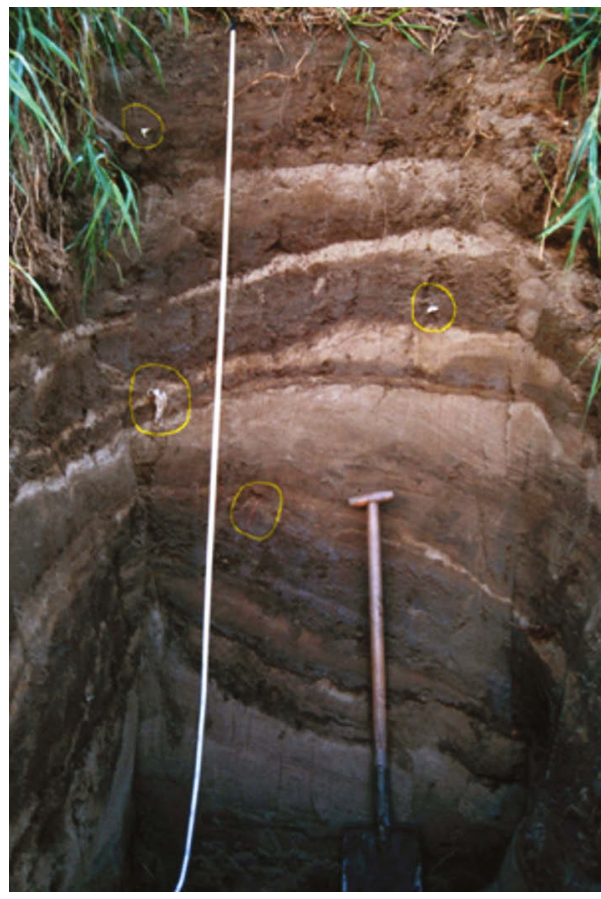

Ryc. 12.3. Osady wału brzegowego w Bieńkowicach

Głębokość odsłonięcia $300 \mathrm{~cm}$. Na żółto zakreślono artefakty określające wiek osadów (płytki PCV, folie, fragmenty opakowań wskazują akumulację ponad 2,5-metrowej warstwy osadów w ciągu około 50 lat; fot. A. Czajka) poziom wody. Osady te ograniczone są kamienną opaską znaczącą brzegi rzeki w połowie XIX w., a w niektórych miejscach niewysoką krawędzią, która wskazuje szerokość koryta współczesnego, mniejszą o kilka, a nawet kilkadziesiąt metrów od koryta w XIX w. W ostatnich kilku latach, $w$ związku $z$ budową polderu i zbiornika koło Raciborza w ramach programu Odra 2006, wykonano kamienne umocnienia brzegów oraz - wzdłuż niektórych odcinków, np. koło Grzegorzowic - serię kilkumetrowych ostróg, które przyczynić się mogą do okresowej intensyfikacji erozji dna koryta i eliminacji erozji brzegów.

Począwszy od ujścia Kłodnicy w Koźlu, aż do Wrocławia, pogłębianie koryta Odry zaznaczyło się w XIX w. i zostało zatrzymane budową kaskady progów wodnych na przełomie XIX i XX w. Wielkość pogłębienia można szacować na $2 \mathrm{~m}$. Poniżej Koźla terasie zalewowej wysokości około $4 \mathrm{~m}$ w niektórych odcinkach towarzyszy niższy poziom zalewowy wysokości koron ostróg, będący skutkiem wypełnienia przybrzeżnej części basenów międzyostrogowych. Osady pylasto-ilaste, budujące ten poziom, wypełniają zarówno baseny międzyostrogowe $z$ tego 


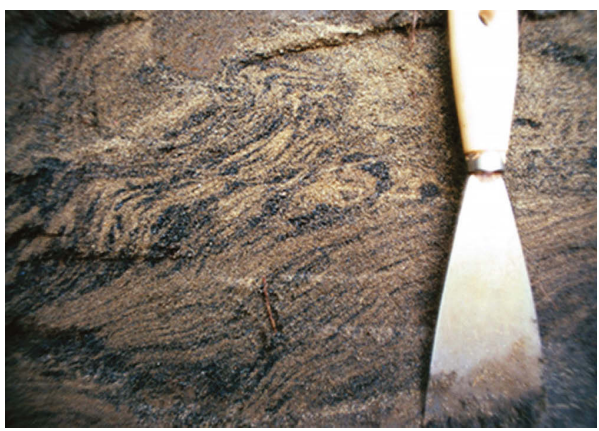

Ryc. 12.4. Przekątna laminacja riplemarkowa w litofacji piaszczystej zdeponowanej na głębokości 230-210 cm (fot. A. Czajka)

Struktura osadów podkreślona obecnością miału węglowego, miejscowość Przewóz.

okresu, jak i pokrywają ponad półmetrową warstwą kamienne opaski brzegowe $z$ przełomu wieków. Stosunkowo szybka depozycja osadów od początku $\mathrm{XX}$ w. jest ograniczona do nisko położonego poziomu i miejsc chronionych ostrogami. W niewielkich basenach międzyostrogowych występują osady pylasto-ilaste, będące wynikiem selektywnej erozji zachodzącej w czasie stanów wody wyższych od przeciętnych. Tempo nadbudowywania XVIII- i XIX-wiecznej terasy zalewowej jest znacznie niższe. Miąższość osadów akumulowanych w XX w., w odległości kilkunastu metrów od współczesnego brzegu, rzadko przekracza $20 \mathrm{~cm}$.

W Krapkowicach w początku XIX w. (ryc. 12.5.) szerokość naturalnego koryta dochodziła do $250 \mathrm{~m}$. W wyniku jego zwężenia, do około $100 \mathrm{~m}$ w połowie XIX w., istniejąca duża łacha żwirowa na prawym brzegu została odcięta i zaczęła być nadbudowywana osadami pylasto-piaszczystymi. Ich miąższość w sąsiedztwie brzegów koryta $z$ tego okresu przekracza $1 \mathrm{~m}$. Skokowy wzrost zanieczyszczenia metalami ciężkimi wskazuje, że połowa $z$ nich została zdeponowana od początku XX w. (Ciszewski 2006). Większej miąższości osady gromadziły się w obniżeniach terenu wokół dawnej łachy, w XX w. nawet około $1 \mathrm{~m}$. W wypełnieniach basenów międzyostrogowych, utworzonych w połowie XIX w., gromadziły się osady pylaste, w dolnej części wzbogacone w okruchy miału węglowego. Ich obecność wskazuje na znaczące zanieczyszczenie Odry w górnej części środkowego biegu już w drugiej połowie XIX w. zrzutami wód dołowych z szybko rozwijających się kopalń węgla na Górnym Śląsku. Miąższość XIX-wiecznych osadów wypełniających jest trudna do ustalenia, ponieważ zostały one zrównane podczas budowy nowych umocnień brzegów, prowadzonej na przełomie XIX i XX w.

W odcinku skanalizowanym Odry depozycja osadów w strefie międzywala w drugiej połowie XX w. była mniejsza niż w górnym biegu i wynosiła około 2000 ton na kilometr biegu rocznie (Łajczak 1995). Erozja koryta jest źródłem transportowanych osadów, szczególnie w czasie ekstremalnych powodzi, a jej świadectwem są osady piaszczyste, lokalnie nawet kilkudziesięciocentymetrowej miąższości, tworzące formy wałów brzegowych (Szponar 2000). Miąższość takich osadów wyraźnie zmniejsza się z biegiem rzeki (Ciszewski 2002).

Współczesną równinę zalewową w międzywalu środkowej Odry można podzielić na trzy strefy o różnej historii depozycji osadów. Schematycznie różnice te w rejonie Oławy są przedstawione na rycinie 12.6. Profil I, w odległości około 150 m od współczesnego brzegu, reprezentuje stare koryto Odry, odcięte w czasie XVIII-wiecznego skracania rzeki. Jest ono całkowicie wypełnione osadami, 


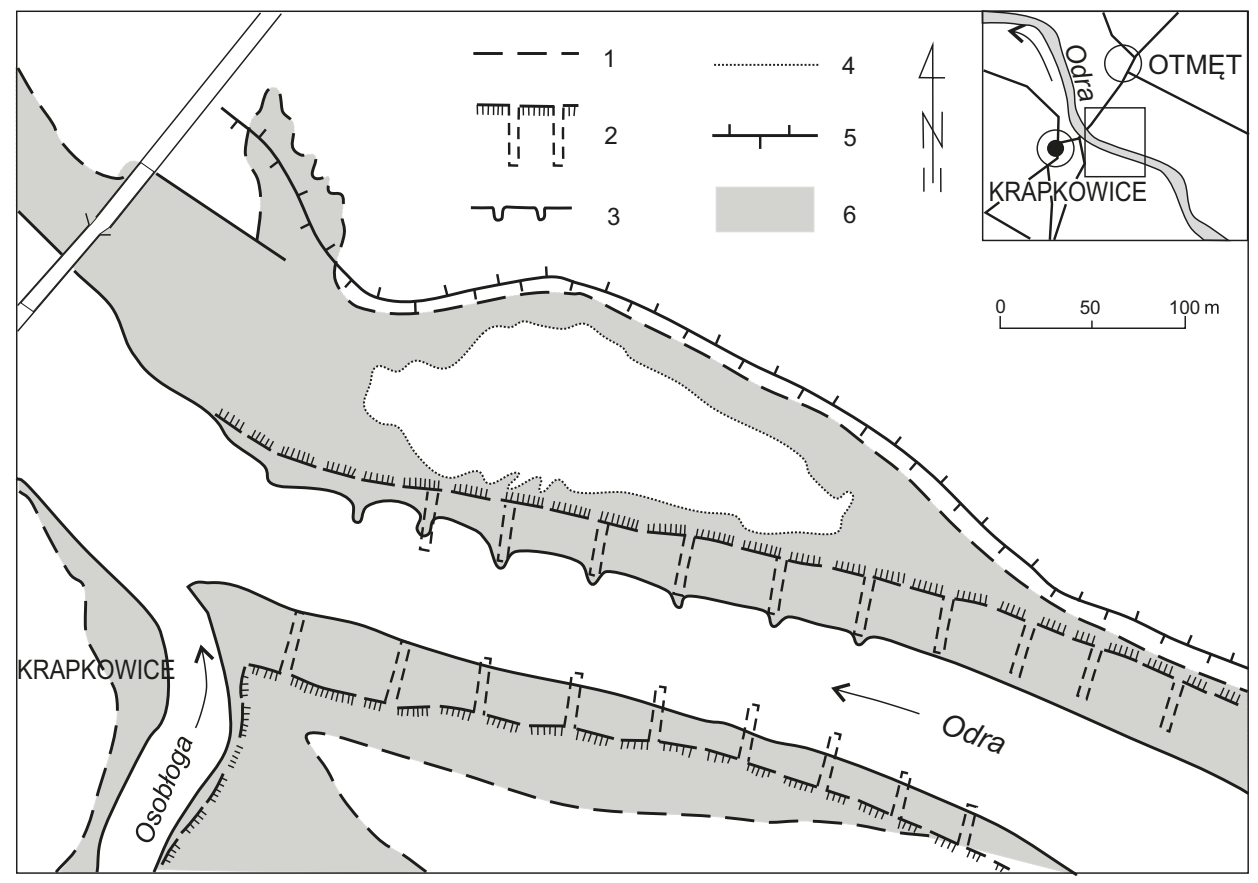

Ryc. 12.5. Uregulowane koryto Odry koło Krapkowic

1 - przebieg koryta w 1825 r., 2 - brzegi i ostrogi w 1851 r., 3 - brzegi i ostrogi współczesne, 4 - łachy korytowe, 5 - wały przeciwpowodziowe, 6 - osady wypełniające XIX-wieczne koryto.

chociaż wciąż widoczne w rzeźbie. W spągu zalegają grubo- i średnioziarniste piaski facji korytowej. Powyżej ujścia Nysy Kłodzkiej fację korytową reprezentują żwiry. Ich cechą charakterystyczną są liczne wytrącenia lub naskorupienia związków manganu i żelaza, świadczące o częstych wahaniach zwierciadła wody. Osady te przykryte są osadami pylastymi z wkładkami piaszczystymi, deponowanymi w czasie powodzi w drugiej połowie XVIII i w XIX w. Na głębokości $20 \mathrm{~cm}$ pojawiają się osady pylaste o znacznej zawartości substancji organicznej i zanieczyszczone cynkiem. Cynk pochodził $z$ istniejącej w Oławie huty cynku, rozbudowanej w drugiej połowie XIX w. Wskazuje to, że powierzchniowa 20-centymetrowa warstwa osadów została złożona w okresie ponad 100 lat. Depozycja osadów w tym miejscu była szybsza w XIX w., a można podejrzewać, że jeszcze szybsza była $\mathrm{w}$ trakcie formowania nowego koryta w XVIII w. Taka sekwencja osadów jest często spotykana w wypełnieniach dawnego koryta Odry (ryc. 12.7).

Profil II usytuowany jest w odległości około $20 \mathrm{~m}$ od współczesnego brzegu $\mathrm{w}$ basenie międzyostrogowym, powstałym około $1843 \mathrm{r}$. Reprezentuje on drugą strefę wypełnień XIX-wiecznych basenów międzyostrogowych. Jej szerokość waha się od kilku do ponad $100 \mathrm{~m}$. Profil znajduje się w wyraźnym wale brzegowym, wznoszącym się do 1,5 m ponad powierzchnię równiny. W spągu profilu znajdują się otoczaki bruku koryta Odry z pierwszej połowy XIX w., na których 


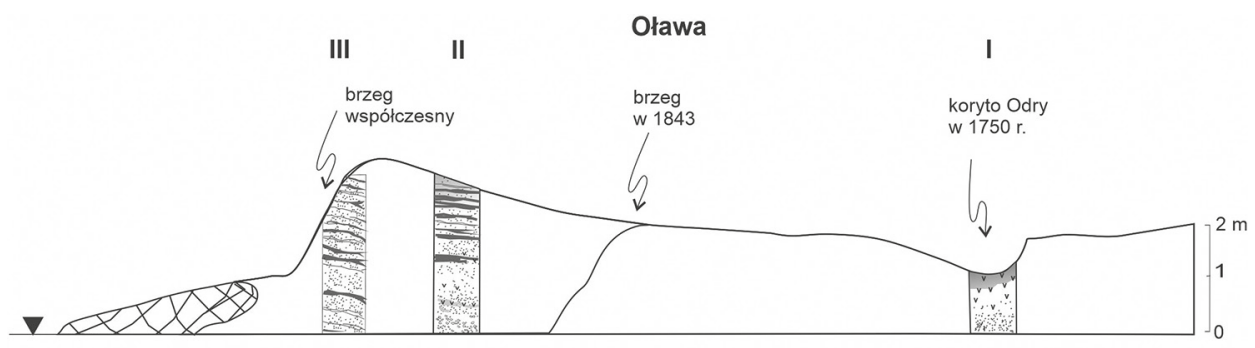

III
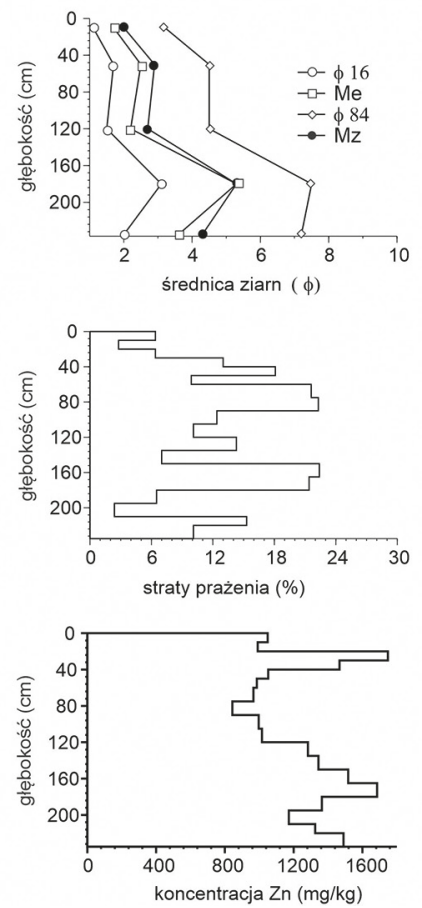

II
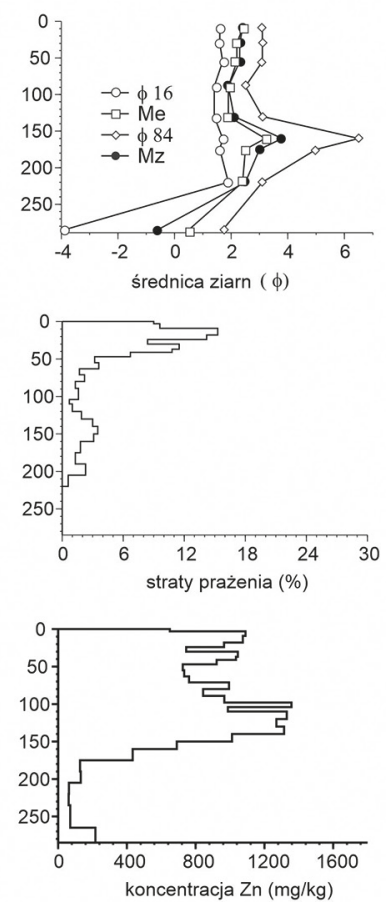

I
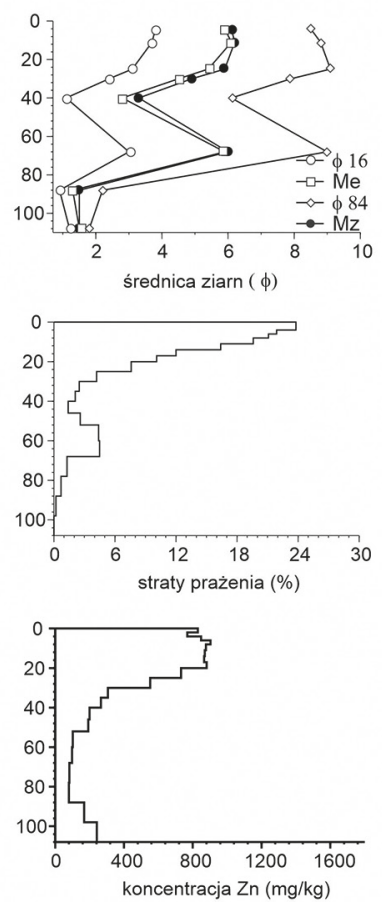

Ryc. 12.6. Stratygrafia i zawartość cynku we współczesnych osadach na równinie zalewowej Odry w strefie międzywala koło Oławy

spoczywają piaski grubo- i średnioziarniste. Reprezentują one osady łachy, które zainicjowały depozycję po utworzeniu pierwszego systemu nieregularnie rozmieszczonych ostróg. Na osadach łachy, od głębokości około 1,5 m, spoczywają, wyraźnie naprzemianlegle warstwowane, osady jasne i brunatnoczarne. Gwałtowny wzrost koncentracji cynku oraz zmiana litologii osadów wskazuje, że część osadów zdeponowanych wcześniej została usunięta w czasie drugiej regulacji koryta około 1905 r. Młodsze osady wału brzegowego składane były więc w ciągu ostatnich 100 lat $\mathrm{w}$ tempie $1-2 \mathrm{~cm} \cdot \mathrm{a}^{-1}$. 
Jeszcze szybsze jest tempo przyrostu osadów wypełniających basen międzyostrogowy, utworzony podczas regulacji z początku XX w. Miąższość osadów wyraźnie warstwowanych, widocznych w odkrywce brzegowej, analogicznych do obserwowanych w XX-wiecznych osadach w górnym biegu, osiąga niemal 2,5 m (ryc. 12.6). Osady te reprezentują trzecią strefę najmłodszych, szybko przyrastających i silnie zanieczyszczonych osadów, wypełniających XX-wieczne baseny międzyostrogowe. W przeciwieństwie do niewielkich basenów, z których osady o słabej kohezji są łatwo erodowane, przy brzegu dużo większych basenów osady piaszczysto-pylaste się zachowują. Cechą charakterystyczną jest jednak występowanie w spągu sekwencji litologicznej - osadów ilasto-pylastych, odpornych na erozję.

Przed II wojną światową Odra była skanalizowana do stopnia Rędzin poniżej Wrocławia, który ulegał podmywaniu wskutek erozji dna. Dla jej zapobieżenia w 1958 r. wybudowano stopień w Brzegu Dolnym. Poniżej

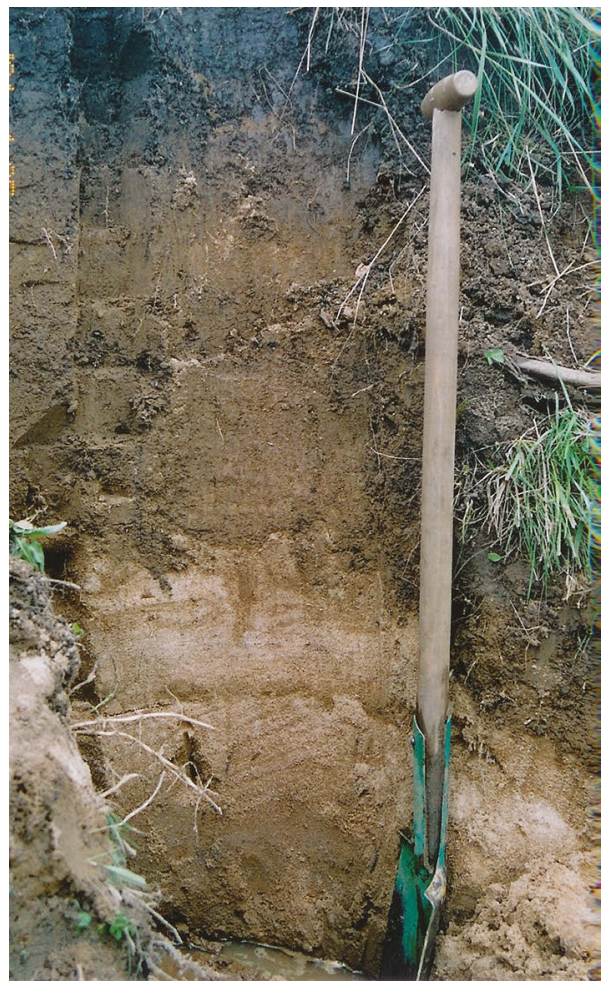

Ryc. 12.7. Współczesne wolno przyrastające osady w środkowym biegu Odry (fot. D. Ciszewski) niego także zaznaczyła się erozja koryta, a średnie obniżenie się jego dna do $1992 \mathrm{r}$. w tempie $5 \mathrm{~cm} \cdot \mathrm{a}^{-1}$ sięgnęło $2 \mathrm{~m}$, zagrażając stabilności progu (Pływaczyk 1997). W 2018 r. oddany został do użytku próg w Malczycach mający wyeliminować to zagrożenie. W planach jest budowa kolejnych, gdyż pogłębienie koryta występuje na odcinku około $50 \mathrm{~km}$ i sięga miejscowości Ścinawa, w niektórych miejscach przekraczając $2,5 \mathrm{~m}$, co powoduje wynurzanie się i wzmożone uszkadzanie ostróg (Jankowski, Świerkosz 1995). Koło Ścinawy dopływa do Odry rzeka Kaczawa, która od początku lat 70. XX w. wnosi duże ilości zanieczyszczeń i osadów związanych z rozwojem Legnickiego Okręgu Miedziowego. Skutkiem oddziaływania Kaczawy, a także prawdopodobnie wzmożonego transportu osadów z erodowanego odcinka powyżej Ścinawy, jest szybkie zapełnianie basenów międzyostrogowych oraz akumulacja osadów na równinie zalewowej. We współczesnych wypełnieniach basenów międzyostrogowych dominują szybko przyrastające słabo skonsolidowane muły z dużą zawartością substancji organicznej. Ich miąższość $\mathrm{w}$ wielu miejscach przekracza $2 \mathrm{~m}$ i jest równa wysokości równiny zalewowej (ryc. 12.8). Wysokie zawartości w nich miedzi wskazują, że osadzały 
się one już po rozpoczęciu wydobycia rud miedzi w 1968 r. W strefie starszych, XIX-wiecznych wypełnień basenów międzyostrogowych, w odległości kilkunastu metrów od współczesnego brzegu, osady akumulowane w analogicznym okresie mają większą zawartość frakcji piaszczystych i są dość wyraźnie warstwowane. Ich miąższość jest bardzo zmienna, jednak rzadko przekracza $1 \mathrm{~m}$. Podścielają je utwory korytowe piasków gruboziarnistych i żwirów, w sekwencji typowej dla środkowego biegu rzeki.

Współcześnie tempo depozycji osadów w przekroju przez strefę międzywala jest bardzo zmienne. Zdecydowanie najwyższe jest w basenach międzyostrogowych przy wewnętrznych brzegach zakoli rzeki. Po powodzi w 1997 r. obserwowano w okolicy Bytomia Odrzańskiego odsypy piaszczyste miąższości do $2 \mathrm{~m}$. Jednak przeważająca ich część została erodowana w czasie następnej powodzi. Zachowane zostały natomiast osady ilasto-pylaste. Skala akumulacji osadów $\mathrm{w}$ kilkudziesięcioletnim okresie, jaki minął od powstania tych basenów, jest mniejsza, jeśli weźmiemy pod uwagę, że mogą one być erodowane już w czasie stanów wody wyższych od średnich. Różnice w tempie akumulacji osadów Odry poniżej Legnickiego Okręgu Miedziowego rejestruje koncentracja miedzi prezentowana na rycinie 12.9 . Osady zanieczyszczone miedzią $\mathrm{w}$ spągu profilu B0 zostały złożone po $1968 \mathrm{r}$. Osady w profilu BI, $5 \mathrm{~m}$ od brzegu, reprezentują wypełnienie basenu międzyostrogowego, także ukształtowanego na początku XX w., ale będącego częścią już powstałego, niższego poziomu równiny zalewowej, wysokości zbliżonej do koron ostróg. Maksimum koncentracji tego pierwiastka, widoczne na głębokości $37 \mathrm{~cm}$, jest związane z maksimum zanieczyszczenia

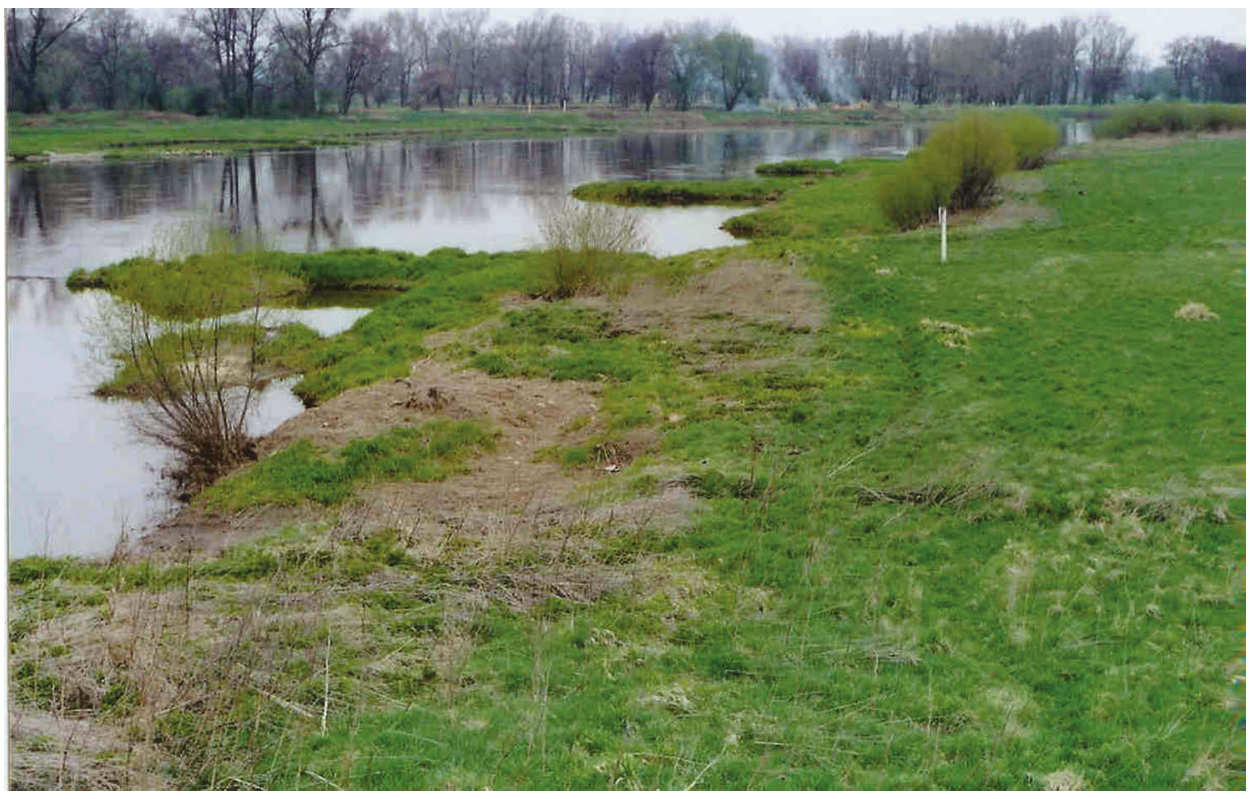

Ryc. 12.8. Wypełnienie basenów międzyostrogowych Odry koło Ścinawy (fot. D. Ciszewski) 
w rejonie Legnicy i wskazuje na tempo akumulacji w tej części równiny rzędu $1,5 \mathrm{~cm} \cdot \mathrm{a}^{-1}$ (Ciszewski 2003). Jest ono nawet 6-krotnie większe niż tempo akumulacji w podobnej odległości od brzegu, ale na równinie zalewowej 2,5-metrowej wysokości, na której warstwa osadów zanieczyszczonych miedzią ma miąższość $20 \mathrm{~cm}$. Generalnie tempo akumulacji osadów zmniejsza się w tym odcinku od maksymalnego w kilku-, kilkunastometrowej szerokości strefie niższego poziomu równiny na obszarze koryta XIX-wiecznego i około 3-6 $\mathrm{mm} \cdot \mathrm{a}^{-1}$ przy krawędzi terasy zalewowej do około 1-2 mm• $\mathrm{a}^{-1} \mathrm{w}$ odległości 100-200 m od brzegu. Maleje ono dalej ze wzrostem odległości. Małe tempo akumulacji osadów w tym odcinku jest uwarunkowane ponad 1,5-kilometrowej szerokości strefą międzywala oraz stabilnością koryta, które ma przebieg zbliżony do obserwowanego w polowie XVIII w. Świadczą o tym fragmenty starorzecza, wciąż jeszcze wypełnione wodą w strefie międzywala, która jest w znacznej części porośnięta lasem.

Mały spadek rzeki poniżej ujścia Nysy Łużyckiej, w połączeniu ze stosunkowo niewielką ilością transportowanego przez Odrę materiału (Łajczak 2005) oraz niewielką amplitudą wahań jej przepływów, powoduje mniejszą depozycję osadów zarówno na równinie, jak i w basenach międzyostrogowych. Efektem tego jest powszechne występowanie basenów międzyostrogowych niewypełnionych nawet w 50\% (ryc. 12.10). W Słubicach długość ostróg wynosi ponad $100 \mathrm{~m}$, a osady w zewnętrznej części basenów tworzą często porośnięte roślinnością wydłużone łachy. Charakterystyczną cechą jest też brak wyraźnych form wałów brzegowych. Natomiast w szerokiej nawet na ponad $2 \mathrm{~km}$ równinie zalewowej bardzo wyraźnie widoczne jest XVIII-wieczne koryto Odry, w znacznej części wypełnione wodą. Maksymalna miąższość osadów, złożonych po ostatniej regulacji na przełomie lat 20. i 30. XX w., wynosi około $30 \mathrm{~cm}$. Szczególnie poniżej ujścia Warty miąższość osadów w sąsiedztwie brzegu nie przekracza kilkunastu centymetrów, z czego po 1968 r. złożonych zostało nie więcej niż kilka centymetrów

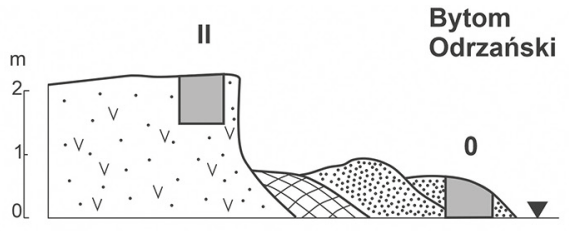

II

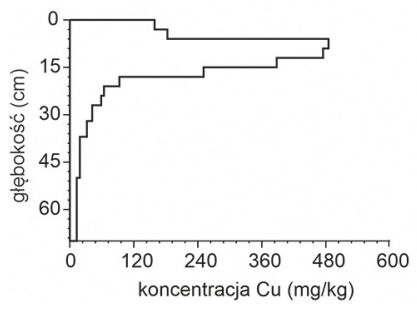

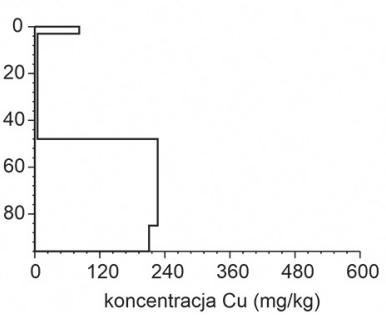

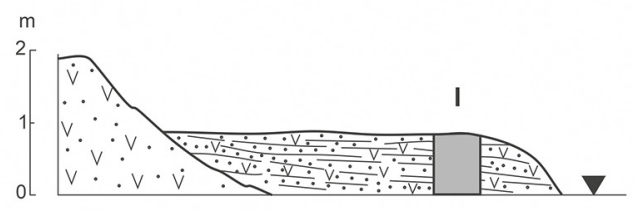

0

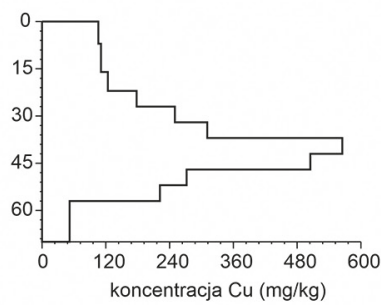

Ryc. 12.9. Zróżnicowanie koncentracji miedzi w XX-wiecznych osadach Odry koło Bytomia Odrzańskiego 
osadów. Często w zatokach, w sąsiedztwie starorzeczy, w świeżo deponowanym osadzie, substancja organiczna dominuje nad materiałem mineralnym.

Regulacja miała kluczowy wpływ na akumulację osadów w XIX i XX w. Są one w większym lub mniejszym stopniu zanieczyszczone metalami ciężkimi, które są dobrymi markerami tych osadów. Schematycznie różnice w rozmieszczeniu osadów ery przemysłowej z biegiem Odry pokazuje rycina 12.11. W górnym biegu, w którym pogłębienie poregulacyjne było największe, osady takie, przeważnie wyraźnie warstwowane, tworzą sekwencje nawet 4-metrowej miąższości w strefie o stosunkowo niewielkiej szerokości wzdłuż brzegu. Szerokość tej strefy przeważnie odzwierciedla szerokość koryta z połowy XIX w. W środkowym biegu osady występują zarówno w strefie przybrzeżnej w sekwencjach nieprzekraczających 2 m miąższości, jak i tworzą niższe poziomy, będące wypełnieniami basenów międzyostrogowych. Spąg tych osadów bardzo często stanowi materiał kohezyjny o dużej zawartości frakcji ilastych. Osady ery przemysłowej tworzą także szersze, kilkudziesięciometrowe strefy, odzwierciedlające szerokość koryta po pierwszej regulacji z połowy XIX w. oraz okrywają kilkunasto-kilkudziesięciocentymetrową warstwą strefę międzywala. W ich spągu najczęściej występują masywne piaski gruboziarniste łach przybrzeżnych. Wreszcie w dolnym biegu, a także w całym granicznym odcinku Odry, osady zanieczyszczone związane z działalnością przemysłową na obszarze zlewni mają małą miąższość, nieprzekraczającą $30 \mathrm{~cm}$ w strefie przybrzeżnej i znacznie wolniejsze, zmniejszające się w kierunku ujścia, tempo przyrostu. Zawartość substancji organicznej jest wysoka jedynie w pojedynczych, głównie powierzchniowych warstwach. Cechą charakterystyczną jest słabo widoczne warstwowanie lub jego brak. Nie tworzą one także wyraźnych

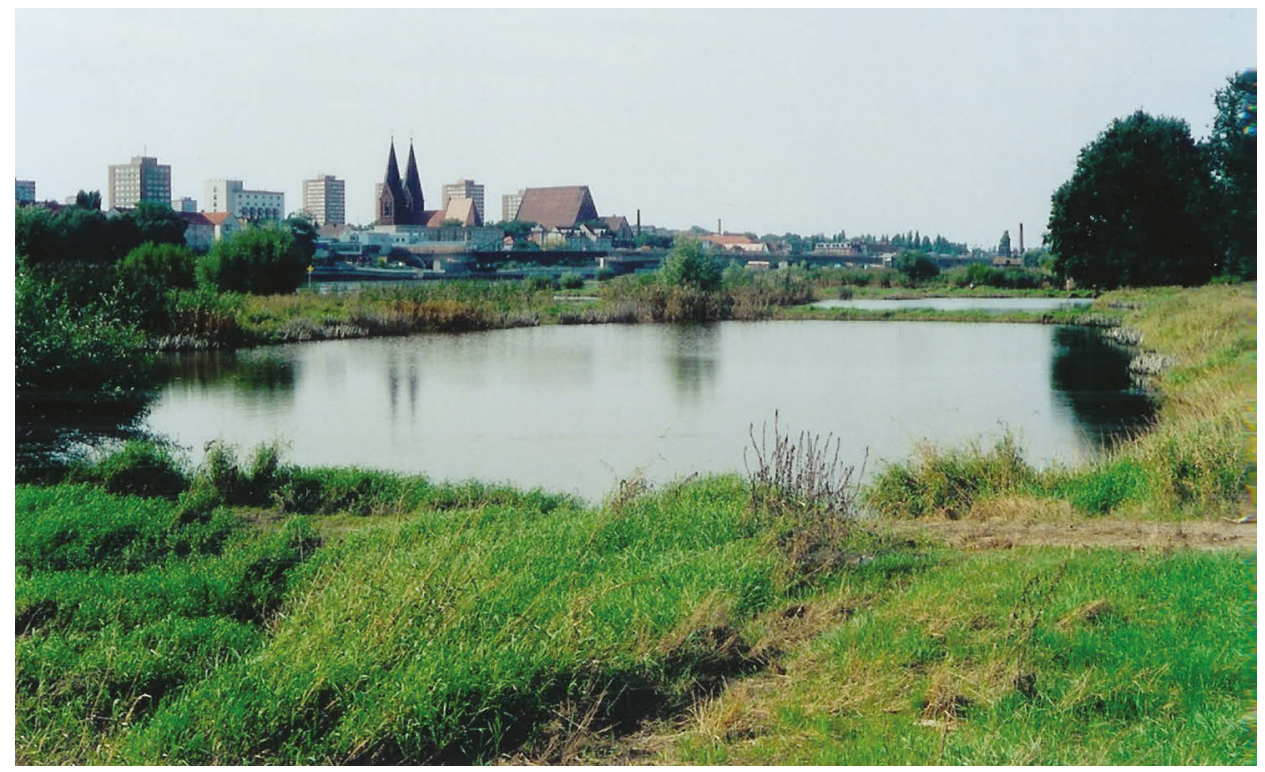

Ryc. 12.10. Baseny międzyostrogowe Odry koło Słubic (fot. D. Ciszewski) 


\section{Odcinek rzeki}

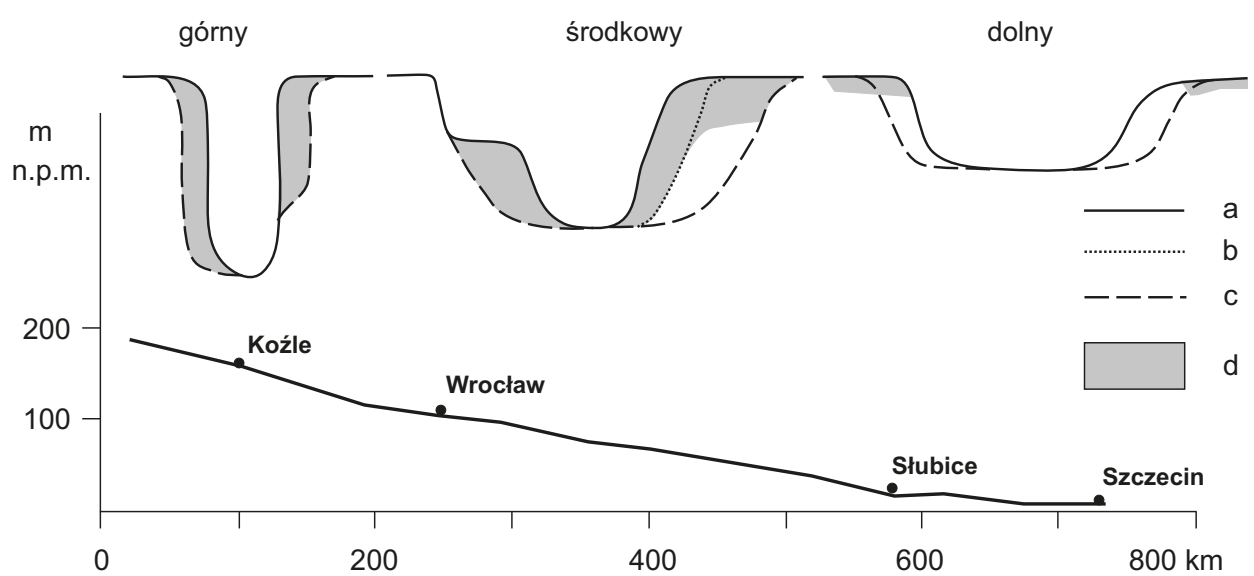

Ryc. 12.11. Rozmieszczenie osadów zanieczyszczonych metalami ciężkimi w górnym, środkowym i dolnym biegu Odry

a - koryto współczesne, b - koryto w początku XX w., c - koryto w początku XIX w., d - osady zanieczyszczone metalami ciężkimi

form szybkiego przyrostu w postaci wałów brzegowych lub odsypów piaszczystych (Ciszewski 2006).

\subsection{Podsumowanie}

Współcześnie zachodzące procesy fluwialne w uregulowanym korycie Odry różnią się jakościowo od występujących w korycie przedregulacyjnym. W miejsce dominującego $\mathrm{w}$ pasie meandrowym lateralnego przyrostu osadów równina nadbudowywana jest dziś wyłącznie przez pionowo przyrastające osady pozakorytowe. Również erozja koryta i depozycja osadów w okresie jego skracania oraz zawężania były większe. $\mathrm{Z}$ czasem intensywność tych procesów została ograniczona, głównie do górnego odcinka rzeki o największej energii. Zainicjowane regulacją wcinanie koryta $\mathrm{w}$ górnym biegu stało się przyczyną powstania nawet 4-metrowych sekwencji warstwowanych osadów, złożonych w dawnym korycie rzeki. Budowa ostróg okazała się kluczowym czynnikiem ograniczającym transfer osadów z koryta na równinę zalewową do epizodów ekstremalnych powodzi. Zainicjowała ona także ekspansję równiny zalewowej, często o wysokości zbliżonej do wysokości równiny naturalnej. Jej cechą charakterystyczną jest występowanie osadów pionowego przyrostu akumulowanych w korycie rzeki na osadach łach korytowych lub na stosunkowo odpornych na erozję osadach ilasto-pylastych. Zachowaniu XIX-wiecznych osadów budujących te równiny, akumulowanych w basenach międzyostrogowych, sprzyjała etapowość zawężania koryta i konstrukcji umocnień brzegowych $w$ XIX i na początku XX w. Umocnienia te są 
bardzo korzystne z punktu widzenia eliminacji gwałtownej erozji osadów i związanego z nimi ładunku zanieczyszczeń. Utrzymywane w dobrym stanie i poddawane ciągłej konserwacji mogą utrwalić obecny stan równowagi form koryta i równiny zalewowej.

\section{Literatura}

Absalon D., Czaja S., Jankowski A.T., Kanok J., Kriz V., 1997, Trends of the river runoff in the Upper Odra River basin, Acta Facultatis Rerum Naturalium Geographia-Geologia, 167, 47-86.

Badura J., Przybylski B., 2000, Korelacja morfologiczna i wiekowa tarasów głównych rzek regionu dolnośląskiego, PIG, Warszawa.

Born A., 1948, Regulacja Odry i rozbudowa urzadzeń technicznych, [w:] A. Grodek, M. Kiełczewska-Zalewska, A. Zierhoffer (red.), Monografia Odry, Instytut Zachodni, Poznań, s. 419-553.

Borówka R.K., 2003, Krajobrazy Zalewu Szczecińskiego i jego otoczenia, Prace Komisji Paleogeografii Czwartorzędu, 1, 89-92.

Ciszewski D., 2002, Akumulacja metali ciężkich w osadach powodzi z 1997 roku, [w:] Z. Denisiuk (red.), Strategia zachowania różnorodności biologicznej i krajobrazowej obszarów przyrodniczo cennych dotkniętych klęska powodzi, IOP PAN, Kraków, s. 33-38.

Ciszewski D., 2003, Heavy metals in vertical profiles of the middle Odra River overbank sediments: evidence for pollution changes, Water, Air and Soil Pollution, 143, 81-98.

Ciszewski D., 2006, Wptyw regulacji koryta Odry ma akumulację osadów zanieczyszczonych metalami ciężkimi: zróżnicowanie, zmiany $w$ czasie, zagrożenie środowiskowe, Studia Naturae, 52, 1-176.

Ciszewski D., Dubicki A., 2008, Reżim hydrologiczny i wspótczesne przemiany koryta i równiny zalewowej Odry, [w:] L. Starkel, A. Kostrzewski, A. Kotarba, K. Krzemień (red.), Wspótczesne przemiany rzeźby Polski, Kraków, s. 371-383.

Czajka A., 2004, Transport i sedymentacja materiału unoszonego w korycie Odry w Kotlinie Raciborskiej, [w:] H. Szymańska, S. Cwojdziński, L. Poprawski (red.), Geologiczne i środowiskowe problemy gospodarowania i ochrony doliny górnej i środkowej Odry, PIG, Wrocław, s. 71-82.

Czajka A., 2005, Accumulation of sediments within the channelized reach of the Upper Odra River, Poland, [w:] Geomorphological Processes and Human Impacts in River Basins, IAHS Publ., 299, 191-196.

Czajka A., Nadudvari A., 2016, Anthropogenic influences on the morphodynamics of the upper Odra channel, Environmental \& Socio-Economic Studies, 4(2): 43-52.

Czerwiński J., 1998, Geologiczne, geomorfologiczne $i$ antropogeniczne uwarunkowania zagrożeń powodziowych we Wroctawiu, Czasopismo Geograficzne, 69, 43-63.

Dubicki A., 1993, Charakterystyka hydrologiczna, [w:] A. Dziubek (red.), Gospodarka zasobami wodnymi dorzecza górnej $i$ środkowej Odry, RZGW, Wrocław, s. 31-42.

Dubicki A., 2002, Das Einzugsgebiet der Oder, [w:] A.K. Meyer (red.), Die Belastung der Oder, Ergebnisse des Internationalen Oderprojekts, 7-9, 21-22.

Galon R. (red.), 1972, Geomorfologia Polski, t. 2, PWN, Warszawa.

Głowicki B., Rzewuski E., Szyjkowski A., 1993, Charakterystyka hydrograficzna, Gospodarka Zasobami Wodnymi Dorzecza Górnej i Środkowej Odry, 23-27.

Jankowski A.T., Křiž V. (red.), 1996, Tendencje zmian obiegu wody w zlewni górnej Odry, Uniw. Śląski, Sosnowiec. 
Jankowski W., Świerkosz K., 1995, Korytarz ekologiczny doliny Odry, IUCN, Warszawa.

Koziarski S., 1997, Funkcja żeglugowa Odry, Czasop. Geogr., 68, 155-180.

Kubec J., 2004, Odra jako czesść przyszłej transeuropejskiej drogi wodnej, Gospodarka Wodna, 2, 61-70.

Łajczak A., 1995, Potential rates of the present-day overbank sedimentation in the Vistula valley at the Carpathian Foreland, southern Poland, Quaestiones Geographicae, 17/18, 41-54.

Łajczak A., 2005, Dostawa materiału unoszonego do Bałtyku przez rzeki, ze szczególnym uwzględnieniem roli Wisty i Odry, Czasop. Geogr., 76, 265-293.

Muszyński W., 1948, Rozwój regulacji Odry, Gospodarka Wodna, 5-6, 127-132.

Matysik M., 2018, Wpływ zrzutów wód kopalnianych na odptyw rzek Górnoślaskiego Zagłębia Weglowego, Wydawnictwo Uniwersytetu Śląskiego, Katowice.

Nalberczyński A., 1993, Charakterystyka ogólna, [w:] A. Dziubek (red.), Gospodarka zasobami wodnymi dorzecza górnej $i$ środkowej Odry, RZGW, Wrocław, s. 9-22.

Plan Gospodarowania Wodami dla Międzynarodowego Obszaru Dorzecza Odry - Raport dla Komisji Europejskiej, 2010, Międzynarodowa Komisja Ochrony Odry przed Zanieczyszczeniem, Wrocław.

Pływaczyk L., 1997, Oddziaływanie spiętrzenia rzeki na dolinę na przykładzie Brzegu Dolnego, Wyd. AR we Wrocławiu, Wrocław.

Szponar A., 2000, Osady pozakorytowe Odry powstate w czasie powodzi w 1997 roku, Przegl. Geol., 48, 176-181.

Unikalna dolina Dolnej Odry, 2015, Nationalpark Unteres Odertal, Schwedt.

Zaleski J., Winter J., 2000, Program dla Odry. Strategia modernizacji odrzańskeigo systemu wodnego. PWN. 